\title{
ANALISIS POLA PENYAJIAN DESKRIPSI PADA NOVEL "SURAT KECIL UNTUK TUHAN" KARYA AGNES DAVONAR SEBAGAI ALTERNATIF PEMILIHAN BAHAN AJAR KELAS XII
}

\author{
Danengsih ${ }^{1}$, Titin Nurhayatin ${ }^{2}$, Adi Rustandi ${ }^{3}$ \\ 1,2,3PBSI FKIP Universitas Pasundan \\ 1'danengsiih26@gmail.com, ${ }^{2}$ titin_nurhayatin@unpas.ac.id, ${ }^{3}$ adirustandi@unpas.ac.id
}

\begin{abstract}
The author analyzed the pattern of presenting descriptions in the novel "Surat Kecil untukTuhan" by Agnes Davonar. The purpose of this study is to describe the pattern of presentation of static descriptions, patterns of presentation of moving descriptions, patterns of presentation of outline descriptions, and describing the results of studies on the pattern of presentation of descriptions in the novel "Surat Kecil untuk Tuhan" by Agnes Davonar can be used as a teaching material Indonesian for class XII learners based on the 2013 Curriculum. The research method use is descriptive qualitative method. Therefore, the data obtained in this study are not in the form of numbers, but in the form of descriptions or narratives. The results showed that in the novel "Surat Kecil untuk Tuhan" by Agnes Davonar, there were 9 patterns of description presentation including, 5 static patterns, 3 moving patterns, and 1 skeleton pattern. The results also showed that based on the results of the analysis of the suitability of study materials with the demands of the curriculum, the novel "Surat Kecil untuk Tuhan" can the results of the study have been validated by experts and declared worthy of use as teaching materials.
\end{abstract}

Keyword: description presentation pattern, teaching materials

\section{ABSTRAK}

Penelitian ini dilatarbelakangi oleh rendahnya minat siswa dalam membaca karya sastra khususnya novel. Selain itu, guru pun merasa kesulitan dalam membuat bahan ajar yang tepat. Dalam penelitian ini, penulis menganalisis pola penyajian deskripsi pada novel "Surat Kecil untuk Tuhan" karya Agnes Davonar. Tujuan dari penelitian ini yaitu, mendeskripsikan pola penyajian deskripsi statis, pola penyajian deskripsi bergerak, pola penyajian deskripsi kerangka, dan mendeskripsikan hasil kajian tentang pola penyajian deskripsi pada novel "Surat Kecil untuk Tuhan" karya Agnes Davonar dapat dijadikan sebagai bahan ajar bahasa Indonesia untuk peserta didik kelas XII berdasarkan Kurikulum 2013. Metode penelitian yang digunakan 
yaitu metode kualitatif. Data yang didapat dalam penelitian bukan berupa angka, melainkan berupa deskripsi atau narasi. Hasil penelitian menunjukkan bahwa pada novel "Surat Kecil untuk Tuhan" karya Agnes Davonar terdapat 9 pola penyajian deskripsi di antaranya, 5 pola statis, 3 pola bergerak, dan 1 pola kerangka. Hasil penelitian juga menunjukkan bahwa berdasarkan hasil analisis kesesuaian bahan kajian dengan tuntutan kurikulum, novel "Surat Kecil untuk Tuhan" dapat dijadikan sebagai alternatif bahan ajar bahasa Indonesia pada kelas XII. Selain itu, hasil penelitian pun sudah divalidasi oleh para ahli dan dinyatakan layak digunakan sebagai bahan ajar.

Kata Kunci: pola penyajian deskripsi, bahan ajar

\section{A. Pendahuluan}

Bahan ajar memiliki posisi sebagai modal awal yang digunakan untuk mencapai suatu hasil. Hasil tersebut dapat berupa pemahaman kemampuan peserta didik dalam memahami suatu materi pembelajaran. Menurut Juwariyah dan Sumartini (2019, hlm. 112), "Pada dasarnya para guru bahasa dan sastra Indonesia mengalami beberapa kendala dalam pembelajaran sastra, salah satunya yaitu guru sering merasa kesulitan dalam menentukan bahan ajar yang tepat, sehingga sering menentukan bahan ajar tanpa memperhatikan kriteria-kriteria tertentu". Berlandaskan pendapat tersebut, dalam pemilihan bahan ajar harus sesuai dengan tingkat usia, kemampuan siswa, dan kualitas karya sastra yang akan dijadikan bahan ajar.

Sastra adalah bagian dari seni.

Sastra sebagai seni menggunakan manusia dalam berbagai aspek kehidupan. Dengan demikian, karya sastra tidak hanya sebagai pembawa gagasan, teori, atau sistem pemikiran, tetapi sebagai sarana penyampaian gagasan, teori, atau sistem pemikiran manusia. Pembelajaran sastra di sekolah sudah diterapkan pada Kurikulum 2013. Pada Kurikulum 2013 peserta didik dituntut untuk lebih kreatif dan aktif dalam pembelajaran, pembelajaran bahasa dan sastra Indonesia memiliki peran penting dalam perkembangan psikologis siswa. Namun, sangat disayangkan bahwa minat siswa dalam pembelajaran sastra di sekolah sangat rendah.

Marliati (2018, hlm. 211-212) menjelaskan tentang pembelajaran karya sastra sebagai berikut.

Upaya kearah pencapaian tujuan 
pembelajaran sastra saat ini masih jauh dari kata maksimal, berkaitan dengan karya sastra di sekolah yang sering ditemukanadalah kurangnya ketersediaan buku-buku sastra, khususnya novel masa kini. Sekolah lebih banyak menyediakan novel-novel lama (angkatan '20-angkatan-'60-an). Sementara siswa membutuhkan internalisasi nilai yang relevan dengan kebutuhan dan problematik kehidupan mereka saat ini.

Pendapat tersebut mengungkapkan bahwa pembelajaran sastra di sekolah belum terlaksana dengan baik, hal ini dikarenakan kurangnya bahan bacaan mengenai karya sastra khususnya novel. Oleh karena itu, pihak sekolah harus menyediakan berbagai macam bacaan yang berkaitan dengan karya sastra. Hal ini bertujuan agar peserta didik dapat berminat dalam pembelajaran karya sastra dan meminimalkan rendahnya minat peserta didik dalam membaca karya sastra.

Seiring perkembangan zaman, karya sastra mengalami perkembangan, baik dalam bentuk maupun isinya. Kosasih (2008, hlm. 7) mengatakan, "Karya sastra terbagi menjadi dua periode, yakni periode sastra lama dan periode sastra baru (modern)". Salah satu periode sastra baru yang dipelajari di kelas XII yaitu novel. Novel termasuk kategori karangan narasi yang berisi rangkaian kehidupan seseorang dengan menonjolkan sifat atau watak dari tokoh.

Dalam setiap karya tulis, karangan dapat disajikan dengan berbagai pola penyajian. Teknik penggunaan pola tersebut biasanya tergantung pada keleluasaan wawasan atau pengalaman penulis. Keraf (2018, hlm. 138) mengatakan, "Dalam membuat suatu karangan deskripsi, objek yang akan dideskripsikan harus memiliki kesatuan".

Berlandaskan pendapat tersebut, kesatuan itu dapat diidentifikasi dengan jelas dan rinci sehingga dapat dimasukkan ke dalam uraian deskripsi. Melalui karangan novel yang bersifat deskripsi, pembaca ingin melihat/merasakan objek atau suasana hati yang digambarkan penulis pada tokoh yang diceritakan secara nyata. Oleh karena itu, menganalisis pola penyajian deskripsi khususnya pada novel akan membantu peserta didik dalam memahami penggambaran objek atau suasana yang diungkapkan pengarang dalam novel tersebut.

Penulis menemukan penelitian 
lain mengenai analisis novel "Surat Kecil untuk Tuhan" karya Agnes Davonar. Penelitian tersebut dilakukan oleh Alda Aprilia Irawanti dan Tanti Agustiani pada tahun 2020 dengan judul, Analisis Nilai Moral dalam Novel "Surat Kecil untuk Tuhan" Karya Agnes Davonar. Dari hasil penelitiannya terdapat penyampaian nilai moral. Nilai moral tersebut terbagi menjadi dua jenis yaitu penyampaian secara langsung dan tidak langsung.

Berdasarkan hal tersebut, penulis merumuskan permasalahan; Bagaimanakah pola penyajian deskrpsi pada novel "Surat Kecil untuk Tuhan" karya Agnes Davonar? 2) Bagaimanakah pola penyajian deskripsi bergerak pada novel "Surat Kecil untuk Tuhan" karya Agnes Davonar? 3) Bagaimanakah pola penyajian deskripsi kerangka pada novel"Surat Kecil untuk Tuhan" karya Agnes Davonar? Dan 4) Apakah hasil kajian tentang pola penyajian deskripsi pada novel Surat Kecil untuk Tuhan karya Agnes Davonar dapat dijadikan sebagai bahan ajar bahasa Indonesia untuk peserta didik kelas XII berdasarkan Kurikulum 2013?

Tujuan dari penelitian ini yaitu mendeskripsikan pola penyajian deskripsistatis pada novel "Surat Kecil untuk Tuhan" karya Agnes Davonar, mendeskripsikan pola penyajian bergerak pada novel "Surat Kecil untuk Tuhan" karya Agnes Davonar, mendeskripsikan pola penyajian kerangka pada novel "Surat Kecil untuk Tuhan" karya Agnes Davonar, dan mendeskripsikan hasil kajian tentang pola penyajian deskripsi pada novel "Surat Kecil untuk Tuhan" karya Agnes Davonar dapat dijadikan sebagai bahan ajar bahasa Indonesia untuk peserta didik kelas XII berdasarkan Kurikulum 2013.

Adapun manfaat teoritis dari penelitian ini yaitu hasil penelitian ini diharapkan dapat menambah wawasan dan pengetahuan mengenai pola penyajian deskripsi dan dapat dijadikan sebagai dasar penelitian selanjutnya. Manfaat praktis penelitian ini yaitu: a) untuk penulis, penelitian ini dapat memberikan manfaat untuk penulis, yaitu menambah wawasan, pengetahuan, dan keterampilan dalam menganalisis pola penyajian deskripsi dalam novel Surat Kecil untuk Tuhan karya Agnes Davonar, b) untuk pendidik, hasil penelitian ini diharapkan dapat menambah wawasan baru pendidik dalam memilih bahan ajar yang bervariasi, c) untuk peserta didik, hasil penelitian ini diharapkan dapat 
membantu peserta didik dalam pembelajaran karya sastra khususnya novel, sehingga pembelajaran karya sastra menjadi sesuai dan menarik sehingga dapat meningkatkan minat peserta didik dalam pembelajaran sastra, d) untuk penulis selanjutnya, hasil penelitian ini diharapkan dapat membantu penulis selanjutnya untuk mengetahui lebih dalam lagi mengenai analisis pola penyajian deskripsi pada novel dan juga sebagai bahan referensi bagi siapapun yang akan melakukan penelitian lanjutan, dan e) dari segi kebijakan, penelitian diharapkan dapat memberikan manfaat kepada orang-orang yang berkecimpung dalam dunia pendidikan khususnya dalam pembelajaran bahasa Indonesia kelas XII. Dengan adanya penelitian, diharapkan hasil kajian ini dapat digunakan sebagai bahan ajar bahasa Indonesia khususnya mengenai materi novel.

\section{B. Metode Penelitian}

Metode yang digunakan dalam penelitian ini yaitu kualitatif deskriptif, yang mana hasil dari penelitian ini menghasilkan data yang bersifat deskripsi dan berupa kata-kata bukan angka.

Adapun teknik pengumpulan data yang digunakan dalam penelitian ini yaitu dokumentasi dan studi pustaka. Menurut Siyoto dan Ali (2015, hlm. 65), "Dokumentasi yaitu mencari data mengenai hal-hal atau variabel yang berupa catatan, transkrip, buku, surat kabar, majalah, sebagainya”. Berdasarkan kutipan tersebut, dokumentasi merupakan teknik pengumpulan data berupa tertulis (seperti gambar, catatan, dan sebagainya). Sedangkan studi pustaka menurut Sugiyono (2019, hlm. 291), "Studi pustaka berkaitan dengan kajian teoritis dan referensi lain yang terkait dengan nilai, budaya, dan norma yang berkembang pada situasi sosial yang diteliti". Maksudnya, studi pustaka tak pernah lepas dari literatur-literatur ilmiah. Oleh karena itu, studi pustaka sangat penting dilakukan dalam penelitian ini.

Teknik pengumpulan data dalam penelitian ini berupa karya sastra prosa yang ditulis oleh Agnes Davonar. Dokumentasi ini difokuskan untuk mengumpulkan data mengenai pola penyajian deskripsi pada novel Surat Kecil Untuk Tuhan karya Agnes Davonar. Sedangkan studi pustaka difokuskan untuk mencari referensireferensi berupa jurnal, skripsi, dan buku yang berkaitan dengan 
penelitian.

Setelah data dikumpulkan, langkah selanjutnya yaitu menganalisis data. Teknik analisis data pada penelitian ini yaitu menggunakan teori Miles dan Hubberman. Miles dan Hubberman dalam Sugiyono (2019, hlm. 246) mengatakan bahwa proses analisis data dikategorikan dalam tiga macam yaitu reduksi data, penyajian data, dan penarikan kesimpulan.

Pada tahap reduksi data, peneliti membaca keseluruhan isi novel Surat Kecil untuk tuhan. Setelah itu peneliti mencatat dan merangkum hal-hal yang pokok berdasarkan ketegorisasi atau melakukan seleksi sesuai dengan penggolongan pada data yang telah dikumpulkan. Pengkategorisasian tersebut dibagi menjadi 3, yaitu 1) pola statis, 2) pola bergerak, dan 3) pola kerangka. Setelah data direduksi, langkah selanjutnya yaitu menyajikan data. Pada tahap ini, data yang disajikan berupa uraian singkat mengenai pola penyajian deskripsi, berupa tabel, dan disusun secara berurutan. Dengan penyajian data ini diharapkan penarikan kesimpulan akan jelas.

Langkah terakhir dalam analisis kualitatif yaitu penarikan kesimpulan serta verifikasi. Pada tahap ini, peneliti mengumpulkan data-data yang telah ditemukan untuk menjawab rumusan masalah yang sudah ditentukan sejak awal sehingga temuan-temuan yang pada awal masih belum jelas menjadi lebih jelas dan rinci.

Setelah data yang ditemukan benar- benar valid, langkah selanjutnya yaitu membuat bahan ajar dan validasi data. Hasil dari analisis tersebut kemudian dijadikan bahan ajar berupa modul Bahasa Indonesia kelas XII. Setelah itu, peneliti melakukan validasi bahan ajar dengan validator ahli. Hal ini bertujuan agar modul yang sudah dibuat layak atau tidak untuk dijadikan bahan ajar di sekolah.

\section{Hasil Penelitian dan Pembahasan}

\section{Hasil penelitian}

Pola penyajian deskripsi adalah bentuk/cara menyampaikan sebuah laporan dalam suatu karangan yang bersifat deskripsi (gambaran mengenai objek). Berikut ini akan diuraikan mengenai hasil analisis pola penyajian deskripsi pada novel "Surat Kecil untuk Tuhan" karya Agnes Davonar.

a. Hasil Analisis Pola Penyajian Deskripsi pada Novel "Surat Kecil untuk Tuhan" Karya Agnes Davonar 
Tabel 1

Hasil Analisis Pola Statis

\begin{tabular}{|c|c|c|}
\hline No & Bukti Kutipan & Hasil Analisis \\
\hline 1. & $\begin{array}{l}\text { "Ketika berjalan di sebuah sudut jalan, aku } \\
\text { melihat pasar binatang yang sedang } \\
\text { mengikuti pameran di sebuah Mal. Aku } \\
\text { melihat kucing manis jenis anggora. Aku } \\
\text { memainkan jarinya di sangkarnya, dan ia } \\
\text { terlihat menjilatku } \\
\text { lembut." }\end{array}$ & $\begin{array}{l}\text { Mengambarkan sesuatu yang dijumpai } \\
\text { pengarang. }\end{array}$ \\
\hline 2. & $\begin{array}{l}\text { “Aku ditempatkan dalam sebuah kamar } \\
\text { dan hanya bersama ayah. Kamar ini } \\
\text { memiliki } \\
\text { dua ranjang bersebelahan dan satu kamar } \\
\text { mandi. } \\
\text { Layaknya sebuah hotel, tapi dilengkapi } \\
\text { dengan berbagai peralatan } \\
\text { kedokteran”. }\end{array}$ & Menggambarkan sebuah ruangan. \\
\hline 3. & $\begin{array}{l}\text { "Pagi-pagi } \\
\text { sekali aku terbangun dan melihat ayah } \\
\text { tidak ada di ruang kamarku. Aku kemudian } \\
\text { melihat jendela yang mengarah ke sebuah } \\
\text { sudut kota. Kulihat banyak sekali orang } \\
\text { yang berada di jalan untuk memulai } \\
\text { aktivitas paginya yang dipenuhi oleh } \\
\text { pepohonan yang indah." }\end{array}$ & $\begin{array}{l}\text { Menggambarkan sebuah tempat yang } \\
\text { mengarah ke sudut kota. }\end{array}$ \\
\hline 4. & $\begin{array}{l}\text { "Tempat dimana aku selalu merasa } \\
\text { bahagia, sebuah kota penuh dengan } \\
\text { arsitektur khas Eropa kuno dengan sebuah } \\
\text { menara tinggi menghiasi kota tersebut, } \\
\text { menara Eiffel. Aku berada di sebuah } \\
\text { negara Eropa Bernama Prancis, tepatnya } \\
\text { di Paris." }\end{array}$ & $\begin{array}{l}\text { Pengarang mendeskripsikan sebuah } \\
\text { tempat yang berada di Paris. }\end{array}$ \\
\hline 5. & $\begin{array}{l}\text { "Aku memperhatikan sebuah rumah yang } \\
\text { indah. Rumah yang berciri khas Prancis. } \\
\text { Rumah tersebut dihiasi dengan bunga } \\
\text { melati di pagarnya yang berwarna putih } \\
\text { dan bersih. Aku sempat bertanya rumah }\end{array}$ & Menggambarkan sebuah rumah. \\
\hline
\end{tabular}




\begin{tabular}{|l|l|}
\hline $\begin{array}{l}\text { indah siapakah yang berdiri di tengah- } \\
\text { tengah kota seperti ini? Ku pandangi setiap } \\
\text { ruas rumah tersebut, tapi pintu pagar yang } \\
\text { tingginya mencapai } 10 \text { meter } \\
\text { menghalangiku untuk masuk. Dan aku } \\
\text { hanya berdiri memperhatikan rumah } \\
\text { tersebut dari luar." }\end{array}$ & \\
\hline
\end{tabular}

Tabel 2

Hasil Analisis Pola Bergerak

\begin{tabular}{|c|c|c|}
\hline No & Bukti Kutipan & Hasil Analisis \\
\hline 1. & $\begin{array}{l}\text { "Selang kecil itu dimasukan ke dalam } \\
\text { tubuhku melalui lubang hidungku. Selang } \\
\text { kecil panjang itu kemudian didorong dari } \\
\text { lubang hidungku menuju bagian jantung } \\
\text { dan paru-paruku dan dari situlah cairan } \\
\text { dikeluarkan." }\end{array}$ & Menggambarkan kinerja selang kecil. \\
\hline 2. & $\begin{array}{l}\text { "Keesokan hari sekitar pukul sembilan } \\
\text { kami memulai perjalanan dari Jakarta } \\
\text { menuju Garut. Dari Garut, tepatnya } \\
\text { kecamatan Wanaraja, aku menuju ke } \\
\text { Bandung yang jaraknya } 80 \text { km dengan } \\
\text { melewati alam pegunungan yang indah } \\
\text { dan udara sejuk." }\end{array}$ & $\begin{array}{l}\text { Menggambarkan perjalanan pengarang ke } \\
\text { kota Bandung. }\end{array}$ \\
\hline 3. & $\begin{array}{l}\text { “Aku berjalan sendirian memperhatikan } \\
\text { setiap toko-toko baju di sampingku yang } \\
\text { penuh dengan pakaian yang tersembunyi } \\
\text { dalam kaca yang nan indah. Semua orang } \\
\text { tersenyum padaku. Mereka sepertinya } \\
\text { mengenal aku, tapi aku tidak mengenal } \\
\text { mereka. Aku terus berjalan tanpa arah.” }\end{array}$ & $\begin{array}{l}\text { Menggambarkan sesuatu yang dijumpai } \\
\text { pengarang dalam perjalanan. }\end{array}$ \\
\hline
\end{tabular}

Tabel 3

Hasil Analisis Pola Kerangka

\begin{tabular}{|c|c|c|}
\hline No. & Bukti Kutipan & Hasil Analisis \\
\hline 1. & $\begin{array}{l}\text { “...kanker yang besarnya di wajahku } \\
\text { sudah sebesar lebih dari buah kelapa } \\
\text { ditambahkan bola tenis." }\end{array}$ & $\begin{array}{l}\text { Mengambarkan wujud dari sebuah } \\
\text { penyakit, yaitu kanker. }\end{array}$ \\
\hline
\end{tabular}


b. Bahan Ajar yang Digunakan

$$
\text { Bahan ajar merupakan }
$$

seperangkat materi pembelajaran yang digunakan untuk membantu pendidik dan peserta didik dalam kegiatan belajar mengajar. Bahan ajar dapat diartikan sebagai bahan yang harus dipelajari oleh peserta didik selama proses pembelajaran berlangsung. Pada penelitian ini, bahan ajar yang dipilih oleh penulis yaitu berupa modul bahan ajar bahasa Indonesia yang disesuaikan dengan tuntutan Kurikulum. Modul tersebut berjudul "Mengidentifikasi Pola Penyajian Deskripsi pada "Novel Surat Kecil untuk Tuhan" Karya Agnes Davonar.

\section{Pembahasan}

a. Pola Penyajian Deskripsi pada Novel "Surat Kecil untuk Tuhan" Karya Agnes Davonar

Dari hasil analisis data, dapat dilihat bahwa pola penyajian deskripsi pada novel "Surat Kecil untuk Tuhan" karya Agnes Davonar terdapat pola penyajian deskripsi. Keraf (2018, hlm. 138) membagi pola penyajian menjadi tiga bagian, yaitu pola statis, pola bergerak, dan pola kerangka. Pola statis yaitu cara pengarang dalam melayangkan pandangan ke objek yang akan dideskripsikan dalam keadaan diam (tidak bergerak). Pola bergerak yaitu cara pengarang menggambarkan suatu objek dari sisi yang bergerak. Seringkali terjadi bahwa deskripsi terhadap sebuah tempat dilakukan dengan bertolak dari suatu segi pandangan yang lain, yaitu pengamat sendiri berada dalam keadaan bergerak. Sedangkan pola kerangka yaitu cara pengarang menggambarkan suatu objek hanya berupa kerangkanya saja. Sering terjadi bahwa sebuah tempat sulit dideskripsikan karena terlalu luas dan besar sehinga sulit untuk mencapai suatu kesan tunggal. Agar penulis dapat mencapai efek kesatuan, maka ia membuat sebuah deskripsi dari sebuah objek yang diamati hanya berupa gambaran kerangkanya saja. Di samping itu, pengarang juga dapat mempergunakan cara lain yaitu membandingkan objek yang luas itu dengan objek yang jauh lebih kecil. Bagian-bagian objek yang luas itu disamakan atau dibandingkan dengan fungsi dari bagian-bagian objek yang kecil tersebut.

Pola penyajian statis merupakan pola terbanyak yang ditemukan oleh penulis dalam novel tersebut, yaitu sebanyak 5 pola statis. Pola statis tersebut di antaranya: 1) pola statis yang isinya menjelaskan mengenai 
sesuatu yang dijumpai pengarang. 2) pola statis yang isinya menjelaskan sebuah ruangan. 3) pola statis yang isinya menjelaskan mengenai sebuah tempat. 4) pola statis yang isinya menjelaskan mengenai tempat yang berada di Paris. 5) pola statis yang isinya menjelaskan sebuah rumah.

Pola bergerak merupakan pola terbanyak kedua yang ditemukan peneliti dalam novel tersebut, yaitu sebanyak 3 pola penyajian bergerak. Pola bergerak tersebut di antaranya: 1) pola bergerak yang isinya menjelaskan mengenai kinerja selang kecil. 2) pola bergerak yang isinya menjelaskan perjalanan pengarang ke kota Bandung. 3) pola bergerak yang isinya mengenai sesuatu yang dijumpai pengarang dalam perjalanan. Pola penyajian deskripsi yang terakhir yaitu pola kerangka. Pola kerangka yaitu mendeskripsikan objek berdasarkan kerangka atau membandingkannya dengan objek yang besar ke objek yang jauh lebih kecil. Dalam novel "Surat Kecil untuk Tuhan" karya Agnes Davonar, peneliti hanya menemukan 1 pola kerangka. Pola tersebut yaitu menjelaskan wujud dari sebuah penyakit, yaitu kanker.

b. Validasi Modul Mengidentifikasi Pola Penyajian Deskripsi pada Novel
"Surat Kecil untuk Tuhan" Karya Agnes Davonar

Setelah penulis membuat modul, penulis melakukan validasi modul tersebut dengan ahli materi. Validasi modul merupakan langkah penting yang harus dilakukan dalam penelitian ini, karena memvalidasi modul ini menentukan layak atau tidak layak modul tersebut digunakan atau diaplikasikan dalam pembelajaran bahasa Indonesia di sekolah.

Modul dengan

judul Mengidentifikaasi Pola Penyajian Deskripsi pada Novel "Surat Kecil untuk Tuhan" Karya Agnes Davonar sudah divalidasi oleh 2 validator. Validator pertama yaitu Bapak Rendy Triandy, M. Pd. selaku dosen di prodi Pendidikan Bahasa dan Sastra Indonesia. Modul tersebut memperoleh nilai 92. Nilai tersebut termasuk ke dalam kriteria "Baik". Beliau menyatakan bahwa modul yang berjudul Mengidentifikaasi Pola Penyajian Deskripsi pada Novel "Surat Kecil untuk Tuhan" Karya Agnes Davonar" sudah bagus secara isi dan pengemasannya, sehingga modul tersebut layak digunakan dalam pembelajaran bahasa Indonesia kelas XII.

Validator kedua yaitu Ibu Ismayni 
selaku guru bahasa Indonesia di SMA Pasundan 3 Bandung. Berdasarkan hasil validasi dengan beliau, modul tersebut memperoleh nilai 94. Nilai tersebut termasuk kriteria "Baik". Beliau menyatakan bahwa pembahasan pada modul sudah sesuai dengan kompetensi inti dan kompetensi dasar, sehingga modul tersebut layak digunakan dalam pembelajaran bahasa Indonesia kelas XII.

\section{Kesimpulan}

Berdasarkan hasil analisis data, penulis menemukan pola penyajian deskripsi pada novel "Surat Kecil untuk Tuhan" karya Agnes Davonar dengan menggunakan metode penelitian kualitatif. Adapun simpulan dari penelitian ini sebagai berikut.

1) Hasil penelitian pada novel "Surat Kecil untuk Tuhan" karya Agnes Davonar menunjukkan 9 pola penyajian deskripsi, di antaranya terdapat 5 pola statis, 3 pola bergerak, dan 1 pola kerangka. Jadi, pola statis pada novel "Surat Kecil untuk Tuhan" karya Agnes Davonar di antaranya: (1) pola statis yang isinya menjelaskan mengenai sesuatu yang dijumpai pengarang. (2) pola statis yang isinya menjelaskan sebuah ruangan. (3) pola statis yang isinya menjelaskan mengenai sebuah tempat. (4) pola statis yang isinya menjelaskan mengenai tempat yang berada di Paris. (5) pola statis yang menjelaskan rumah. 2) Hasil penelitian pada novel "Surat Kecil untuk Tuhan" karya Agnes Davonar menunjukkan 3 pola bergerak, di antaranya: (1) pola bergerak yang isinya menjelaskan mengenai kinerja selang kecil. (2) pola bergerak yang isinya menjelaskan perjalanan pengarang ke kota Bandung.(3) pola bergerak yang isinya mengenai sesuatu yang dijumpai pengarang dalam perjalanan. 3) Hasil penelitian pada novel "Surat Kecil untuk Tuhan" karya Agnes Davonar menunjukkan 1 pola kerangka, yaitu menjelaskan wujud dari sebuah penyakit, yaitu kanker. 4) Hasil penelitian pola penyajian deskripsi pada novel "Surat Kecil untuk Tuhan" karya Agnes Davonar dapat dijadikan sebagai alternatif pemilihan bahan ajar bahasa Indonesia kelas XII. Bahan ajar ini dibuat berdasarkan kesesuaian hasil kajian dengan tuntutan kurikulum yang di dalamnya memuat Kompetensi Inti, Kompetensi Dasar, materi, aspek bahasa, dan perkembangan psikologis peserta didik. Selain itu, hasil analisis pada penelitian ini telah divalidasi oleh para ahli dan dinyatakan layak 
dijadikan sebagai alternatif pemilihan bahan ajar. Adapun saran yang penulis berikan, yaitu: 1) Bagi pendidik, penelitian ini dapat dijadikan sebagai referensi bahan ajar bahasa Indonesia dan menjadi sarana untuk mengajarkan peserta didik dalam mengapresiasi karya sastra mengenai kehidupan dalam novel. 2) Bagi peneliti lain, penelitian ini dapat dijadikan sebagai referensi apabila melakukan penelitian serupa dan diharapkan dapat menganalisis pola penyajian deskripsi pada novel lain. 3) Bagi pembaca umum, penelitian ini dapat dijadikan sebagai sarana untuk mengapresiasi karya sastra dengan menggunakan pola penyajian deskripsi dalam novel tersebut.

\section{DAFTAR PUSTAKA}

Irawanti, dan Tanti. (2020). Analisis Nilai Moral dalam Novel Surat Kecil untuk Tuhan Karya Agnes Davonar. Jurnal Pendidikan Bahasa dan Sastra Indonesia,

$$
\text { 4(2), 98-102. }
$$

Juwariyah, \& Sumartini. (2019). Konflik Batin Tokoh Utama dalam Novel Ada Surga di Rumahku Karya Oka Aurora Sebagai Alternatif Bahan Ajar Pembelajaran Sastra di SMA. Jurnal Sastra Indonesia, 8(2), 111-118.

Keraf, G. (2018). Eksposisi dan Deskripsi. Flores: Nusa Indah.

Kosasih, E. (2008). Apresiasi Sastra Indonesia. Jakarta: Nobel Edumedia.

Marliati, A. (2018). Kajian Simbol dalam Penokohan pada Novel Negeri 5 Menara Karya Ahmad Fuadi: Tinjauan Semiotik Peirce sebagai Alternatif Bahan Ajar Bahasa dan Sastra Indonesia di SMA. Wistara. 1(2), 210-220.

Siyoto dan Ali Sodik. (2015). Dasar Metodologi Penelitian. Sleman: Media Publishing.

Sugiyono. (2019). Metode Penelitian Kuantitatif, Kualitatif, dan R\&D. Bandung: Alfabeta. 